\title{
MENINGKATKAN KEMAMPUAN SISWA SD YPPK SANTO YOSEPH 1 BIAK DALAM MEMAHAMI UNSUR-UNSUR CERPEN
}

\author{
Kiki Erisita Payug \\ Pendidikan Guru Sekolah Dasar, Sekolah Tinggi Keguruan dan Ilmu Pendidikan Biak \\ kikierisntapayung@gmail.com \\ Beatus Mendelson Laka \\ Pendidikan Guru Sekolah Dasar, Sekolah Tinggi Keguruan dan Ilmu Pendidikan Biak \\ lakamendelson@gmail.com \\ Agus Boy Fatubun \\ Pendidikan Guru Sekolah Dasar, Sekolah Tinggi Keguruan dan Ilmu Pendidikan Biak
}

\begin{abstract}
ABSTRAK
Bahasa adalah salah satu komponen cerita. Sebagian besar cerita bahasa terlalu "berat" untuk anakanak. Oleh karena itu, materi tentang cerita anak-anak diambil sebagai salah satu materi dalam pelajaran bahasa Indonesia yang diajarkan di SD YPPK Santo Yoseph 1 Biak terlihat bahwa kemampuan siswa untuk memahami cerita itu baik tetapi unsur intrinsik dari cerita pendek tersebut tidak dengan apa yang diharapkan. Tujuan penelitian ini adalah untuk mengetahui kemampuan kelas VA SD YPPK Saint Yoseph 1 Biak dalam menganalisis unsur intrinsik cerpen. Jenis penelitian ini adalah penelitian Tindakan Kelas dengan menggunakan dua siklus. Populasi yang digunakan sebagai objek penelitian adalah siswa kelas VA SD YPPK St. Yoseph 1 Biak, yang terdiri dari 23 orang yang terdiri dari 11 wanita dan 12 pria. Teknik pengumpulan data observasi, tes dan penentuan skor. Hasil penelitian ini adalah siswa VA SD YPPK St. Yoseph 1 telah mampu memahami unsur intrinsik cerpen dengan baik dan benar.

Kata Kunci: Kemampuan Siswa, Unsur Intrinsik, Cerita Pendek
\end{abstract}

\begin{abstract}
Language is one component of the story. Most of the language stories are too "heavy" for children. Therefore, the material about children's stories is taken as one of the materials in Indonesian language lessons taught at SD YPPK Santo Yoseph 1 Biak. It can be seen that the students' ability to understand stories is good, but the intrinsic elements of the short stories are not what was expected. The purpose of this study was to determine the ability of class VA SD YPPK Saint Yoseph 1 Biak in analyzing the intrinsic elements of short stories. This type of research is a classroom action research using two cycles. The population used as the research object was the students of class VA SD YPPK St. Yoseph 1 Biak, consisting of 23 people consisting of 11 women and 12 men. Observation data collection techniques, tests and scoring. The results of this study were the VA students of SD YPPK St. Yoseph 1 has been able to understand the intrinsic elements of the short story properly.

Keywords: Student Ability, Intrinsic Elements, Short Stories
\end{abstract}

\section{PENDAHULUAN}

Cerpen adalah cerita yang dalam

bentuk fiksi pendek. Panjang pendek sebuah cerita adalah relatif. Namun secara umum cerita pendek adalah cerita yang bertuliskan sekitar sepuluh menit atau setengah jam. Ringkasnya sekitar 500-5000 kata kata. Karena itu sering diungkapkan dengan cerita yang tepat dibaca dalam satu duduk.

Elemen intrinsik adalah elemen yang membentuk karya sastra. Elemen 
tersebut ditemui jika kita telah membaca karya sastra. Elemen intrinsik dari sebuah cerita pendek adalah sebuah elemen yang dapat secara langsung membangun cerita dan keterpaduan antara elemen-elemen yang membuat cerita pendek menjadi kenyataan. Pembaca dapat dengan mudah menentukan elemen intrinsik yang terkandung dalam cerita. Elemen intrinsik adalah elemen yang membentuk karya sastra dalam hal penokohan, tema, mandat, latar belakang, alur, dan gaya bahasa.

Sedangkan unsur ekstrinsik adalah unsur yang membangun karya sastra dari luar sastra yaitu: latar belakang kehidupan penulis, pandangan hidup penulis, situasi sosial, latar belakang budaya lahirnya karya sastra. tetapi elemen ekstrinsik tidak dibahas secara rinci. Yang dibahas hanyalah elemen intrinsik saja.

Bahasa adalah salah satu komponen cerita. Ketika kita berbicara tentang bentuk bahasa, yang kita maksud adalah kata, frasa, klausa, kalimat, paragraf, dll, yang diucapkan dan ditulis (Swarniti, 2019). Sebuah cerita mungkin berpotensi menarik, tetapi jika bahasanya buruk, itu tidak akan pernah mencapai anak-anak dan tidak akan pernah menjadi milik anak-anak. Kebanyakan guru menggunakan metode ceramah dalam menyampaikan materi kepada siswa, tentang banyak metode dan model pembelajaran yang harus digunakan dalam proses pembelajaran sehingga siswa juga lebih sadar akan apa yang disampaikan oleh guru. Oleh karena itu, dalam penelitian ini penulis menggunakan metode STAD Cooperative Type dalam menyampaikan unsur intrinsik dari bahan cerita pendek, materi tentang cerita anak-anak diambil sebagai salah satu bahan pelajaran bahasa Indonesia yang diajarkan di sekolah dasar VA (SD). Ini akan membuat teks bagus dan mudah dibaca (Swarniti, 2021).

Berdasarkan pengamatan yang dilakukan oleh penulis di SD YPPK Santo Yoseph 1 Biak terlihat bahwa kemampuan siswa memahami unsur intrinsik cerpen tidak sesuai dengan apa yang diharapkan. Hal ini terlihat pada hasil yang dicapai oleh siswa, karena dalam penyampaian materi kepada siswa tidak monoton guru sehingga hasilnya belum maksimal.

Nurgiantoro dalam (Peni N.H, 2010: 23) tema adalah makna yang disampaikan oleh sebuah cerita. Tema ini biasanya diangkat dari berbagai masalah kehidupan seperti keluarga, ekonomi, pendidikan, sosial, agama, adat istiadat dan sebagainya. Nurgiantoro (2005:80) menjelaskan bahwa tema adalah cerita dapat dipahami sebagai suatu makna. Makna itu mengikat seluruh elemen cerita sehingga muncul sebagai satu kesatuan. 
Dari beberapa pengertian di atas, dapat disimpulkan bahwa tema dalam sebuah cerita adalah ide sentral yang melatarbelakangi sebuah cerita, adalah gagasan umum yang menopang karya sastra. Tema ini menjadi dasar untuk pengembangan cerita dan menggerakkan seluruh bagian cerita. Oleh karena itu, untuk menentukan tema karya sastra, itu harus disimpulkan dari keseluruhan cerita, tidak hanya berdasarkan bagian-bagian tertentu. Penafsiran tema dibutuhkan oleh pemahaman cerita secara keseluruhan.

Menurut Poerwadarminta (2011:87), karakter adalah orang yang berperan dalam karya sastra. Dalam hubungan itu karakterisasi adalah proses penampilan suatu karakter dengan memberikan karakter (Santika, 2017), sifat atau kebiasaan dari karakter seorang aktor cerita. Mereka terlihat dalam fiksi (aksi dan ucapan). Figur adalah pelaku yang mengembangkan peristiwa dalam cerita fiksi sehingga cerita adalah cerita, sedangkan cara penulis menampilkan karakter yang disebut karakterisasi.

$$
\text { Nurgiantoro }
$$
menjelaskan bahwa alur adalah aspek utama yang harus dipertimbangkan karena aspek inilah yang menentukan daya tarik cerita dan memiliki kekuatan untuk melibatkan pembaca secara total mengikuti cerita. Berdasarkan pendapat di atas, penulis menyimpulkan bahwa plot dimaksud dengan serangkaian peristiwa atau peristiwa yang diselenggarakan berdasarkan hukum sebab akibat.

Latar belakang dalam bahasa Indonesia sering diterjemahkan sebagai latar belakang. Di bawah ini akan disajikan beberapa pendapat tentang latar, antara lain: Poerwadarminta (2011: 128), menyebutkan bahwa latar belakang adalah waktu dan tempat peristiwa dalam sastra atau drama, atau pemandangan pemandangan yang digunakan dalam permainan seperti pengaturan adegan, perlengkapan, dan pengaturan pencahayaan. Tjahyono (dalam Peni N., H, 2010: 28) mengungkapkan bahwa latar belakang atau yang biasa juga disebut dengan setting, yaitu tempat, waktu dan keadaan atau peristiwa yang terjadi dalam sebuah karya sastra. Tarigan (1984:136), menyatakan bahwa deskripsi atau lukisan di latar belakang tidak hanya harus dilihat dalam pengertian gagasan yang sesuai dengan kenyataan, tetapi juga harus dilihat dari aspek apa yang paling baik disajikan untuk sebuah cerita.

Sejalan dengan Wahid (2004: 38) bahwa sudut pandang adalah tempat bercerita dalam kaitannya dengan cerita, dari aspek posisi bercerita. Dari beberapa pendapat di atas tentang sudut pandang narator, penulis menyimpulkan bahwa yang dimaksud dengan sudut pandang narator adalah penempatan penulis dalam menggambarkan cerita. 
Pembelajaran kooperatif tipe

STAD adalah salah satu jenis model pembelajaran kooperatif dengan menggunakan kelompok kecil yang jumlah anggotanya masing-masing kelompok 4-5 siswa secara heterogen. Dimulai dengan menyampaikan tujuan pembelajaran, penyampaian materi, kegiatan kelompok, kuis dan penghargaan kelompok Trianto (2010: $68)$.

Slavin dalam (Nur, 2000: 26) menyatakan bahwa dalam STAD siswa ditempatkan dalam tim belajar beranggotakan 4-5 orang yang merupakan campuran antara prestasi, jenis kelamin, dan etnis. Guru mempresentasikan pelajaran, dan kemudian siswa mengerjakan tim mereka untuk memastikan bahwa semua anggota tim telah menguasai pelajaran. Kemudian, semua siswa diberikan tes pada materi, pada saat tes ini mereka tidak diperbolehkan untuk saling membantu.

Langkah-langkah dalam pembelajaran kooperatif tipe STAD (Divisi Prestasi Tim Mahasiswa) meliputi: 1) Membentuk kelompok yang anggotanya 4-5 orang heterogen sesuai dengan prestasi, jenis kelamin dan etnis, 2) Guru menyajikan pelajaran, dan guru menugaskan tugas kelompok untuk dikerjakan oleh anggota kelompok. Anggota yang sudah mengerti, dapat menjelaskan kepada anggota lain hingga semua anggota dalam kelompok mengerti Trianto (2010: 70).

Menurut (Isjoni, 2010:

Kelemahan pembelajaran kooperatif tipe STAD antara lain sebagai berikut: Berdasarkan karakteristik STAD, jika dibandingkan dengan pembelajaran konvensional (yang hanya merupakan penyajian materi dari guru), belajar menggunakan model ini membutuhkan waktu yang relatif lama, dengan mempertimbangkan tiga langkah STAD yang menguras waktu seperti presentasi materi dari guru, kerja kelompok dan tes individu. Sementara membentuk kelompok dan pengaturan ruang kelas sesuai dengan kelompok yang ada dapat dilakukan sebelum kegiatan pembelajaran dilaksanakan. Dengan demikian, dalam kegiatan pembelajaran tidak ada waktu yang terbuang untuk pembentukan kelompok dan penyelenggara kelas. Model ini membutuhkan keterampilan khusus dari guru.

Guru dituntut sebagai fasilitator, mediator, motivator dan evaluator Isjoni (2010: 62). Menurut Rusman (2011: 204) keunggulan belajar kooperatif tipe STAD antara lain sebagai berikut: 1) Siswa memiliki dua bentuk tanggung jawab, yaitu belajar untuk diri mereka sendiri dan membantu sesama anggota kelompok untuk belajar, 2) Siswa saling belajar dari sesama siswa lain atau pelajaran dengan teman sebaya 
(peerteaching) lebih efektif daripada pembelajaran guru, 3) Pengelompokan siswa yang heterogen membuat komposisi yang terjadi di kelas lebih hidup, 4) Prestasi belajar dan hasil belajar yang baik dapat diperoleh oleh semua anggota kelompok, 5) Kuis dalam langkah-langkah pembelajaran membuat siswa lebih termotivasi, 6) Kuis memunculkan tanggung jawab individu, karena nilai akhir kelompok dipengaruhi oleh nilai khusus yang dilakukan secara individual, 7) Ada apresiasi dari guru, sehingga siswa lebih termotivasi untuk aktif dalam pembelajaran, dan 8) Anggota kelompok dengan prestasi dan hasil belajar yang rendah memiliki tanggung jawab besar untuk memastikan bahwa nilai yang diperoleh tidak rendah sehingga nilai kelompok itu baik.

Pembelajaran sastra memiliki peran penting dalam mencapai berbagai aspek tujuan pendidikan dan pengajaran pada umumnya. Aspek-aspek ini adalah aspek pendidikan, sosial, perasaan, penilaian sikap, dan agama.Tujuan pembelajaran sastra mencakup dua hal, yaitu untuk memperoleh pengalaman sastra dan memperoleh pengetahuan sastra. Tujuan memperoleh pengalaman sastra dapat dicapai dengan mengalami secara langsung atau langsung untuk melihat hal-hal yang berkaitan langsung dengan kegiatan sastra. Misalnya, siswa terlibat langsung membaca sastra, mendengarkan karya sastra dan disuruh menulis karya sastra. Pembelajaran sastra dapat membantu siswa mengenali diri mereka sendiri, budaya mereka, dan budaya orang lain.

\section{METODE}

Penelitian ini adalah peserta Penelitian Tindakan Kelas (PTK). Suatu penelitian dikatakan partisipan adalah jika orang yang akan melakukan penilaian harus terlibat langsung dalam proses penelitian dari awal hingga hasil penelitian dalam bentuk laporan. Dengan demikian, sejak perencanaan penelitian, peneliti selalu terlibat, peneliti memantau, mencatat, dan mengumpulkan data, kemudian menganalisis data dan mengakhiri dengan melaporkan hasil penelitiannya (Iskandar, 2010: 27). Dalam penelitian ini, peneliti terlibat langsung secara terus menerus dari awal hingga akhir penelitian, selain itu peneliti juga melibatkan siswa, guru Bahasa Indonesia yang mengajar di kelas, sehingga penelitian ini memberikan hasil yang optimal. Subjek penelitian ini adalah semua siswa kelas VA SD YPPK St. Yoseph 1 Biak yang terdiri dari 23 orang yang terdiri dari 12 pria dan 11 wanita.

Prosedur penelitian adalah refleks awal, perencanaan tindakan, implementasi tindakan, observasi dan evaluasi serta refleksi. Pengumpulan data dan instrumen penilaian penulis menggunakan metode observasi, tes dan 
penentuan skor. Analisis pertama, dilakukan pada implementasi tindakan yang diambil, apakah implementasi sesuai dengan yang direncanakan. Kedua, analisis kemampuan untuk memahami unsur intrinsik cerpen melalui pembelajaran kooperatif tipe STAD yang diperoleh dari hasil tes. Hasil tes diproses menggunakan keberhasilan belajar individu dan klasik. Penilaian hasil tes setiap siswa dianalisis dengan norma absolut dari seratus skala. Skala seratus adalah skala yang bergerak dari nol ke seratus. Skala keseratus juga disebut skala persentil. Setelah mengetahui nilai masing-masing siswa, maka secara klasik dapat dicari nilai rata-rata dengan menggunakan rumus berikut:

$$
\begin{aligned}
& \text { Berarti }=\frac{\Sigma F X}{N} \\
& \text { Deskripsi: } \\
& \text { Berarti = Nilai Rata-rata } \\
& \text { F = Frekuensi }
\end{aligned}
$$

$$
\begin{aligned}
& x=\text { Nilai } \\
& \text { N = Jumlah Sampel } \\
& \text { Nurkencana (1992: 99). }
\end{aligned}
$$

\section{HASIL DAN PEMBAHASAN}

$$
\text { Pengamatan dilakukan oleh }
$$
peneliti dengan guru mata pelajaran Bahasa Indonesia. Dari pengamatan ini dapat diketahui masalah siswa dalam mengikuti pelajaran bahasa Indonesia khususnya cerpen. Hasil pengamatan yang telah dilakukan adalah: (1) pembelajaran yang diterapkan guru adalah konvensional, (2) siswa hanya mengandalkan catatan dari guru dan berdasarkan LKS, (3) siswa kurang termotivasi, anak-anak yang memiliki motivasi tinggi dalam melakukan tugas akan lebih banyak (4) siswa takut bertanya kepada guru tentang hal-hal yang kurang dan jelas, (5) siswa tidak mengerti bagaimana menemukan atau menganalisis unsur intrinsik cerpen.

Tabel 1. Analisis Data Tes Awal Meningkatkan Elemen Intrinsik Menganalisis Cerita Pendek Melalui Pembelajaran Kooperatif STAD Kelas VA SD Santo Yoseph YPPK 1 Tahun Akademik 2016/2017

\begin{tabular}{|c|c|c|c|c|c|c|}
\hline No & value (x) & $\mathbf{F}$ & $\mathbf{F x}$ & Presentase & Category & \multirow{2}{*}{ verage Value } \\
\hline$(\mathbf{1})$ & $\mathbf{2})$ & $\mathbf{( 3 )}$ & $\mathbf{4})$ & $\mathbf{( 5 )}$ & $\mathbf{6}$ & \multirow{2}{*}{ 7) } \\
\hline 1 & 0 & - & - & - & - \\
\hline 2 & 9 & - & - & - & - \\
\hline 3 & 8 & - & - & - & - \\
\hline 4 & 7 & - & - & - & - \\
\hline 5 & 6 & - & - & - & Emost enough \\
\hline 6 & 5 & 7 & 35 & $30,4 \%$ & \\
\hline
\end{tabular}




\begin{tabular}{|c|c|c|c|c|c|c|}
\hline 7 & 4 & 9 & 36 & $39,2 \%$ & ess & $\frac{92}{23}$ (less) \\
\hline 8 & 3 & 7 & 21 & $30,4 \%$ & ess so \\
\hline 9 & 2 & - & - & - & - \\
\hline 10 & 1 & - & - & - & \\
\hline
\end{tabular}

Data pada Tabel 2 di atas menunjukkan bahwa kemampuan siswa untuk menganalisis unsur intrinsik cerita dalam tes awal, siswa mencapai nilai rata-rata 4,00 dengan nilai lima kategori hampir cukup sebanyak 7 orang (30,4\%), kurang total nilai 4 kategori 9 orang $(39,2 \%), 3$ kategori skor kurang sekali sebanyak 7 orang $(30,4 \%)$, dari hasil yang diperoleh siswa dapat disimpulkan bahwa kemampuan menganalisis unsur intrinsik cerpen pada tes awal bisa dikategorikan kurang, ini bisa dilakukan di SD YPPK Santo Yoseph 1 Biak.
Setelah implementasi kegiatan aksi atau pembelajaran, maka dilakukan evaluasi. Kegiatan evaluasi dilakukan untuk mengetahui lebih lanjut tentang kemampuan memahami isi bacaan siswa. Dalam implementasi evaluasi, peneliti memberikan tes. Tes ini bertujuan untuk mengetahui kemampuan siswa dalam memahami isi bacaan dalam paragraf dengan penerapan model pembelajaran kooperatif tipe STAD. Hasil tes dapat dilihat pada tabel berikut.

Tabel 2. Analisis Data Siklus I Siwa Meningkatkan Unsur Intrinsik Menganalisis Cerita Pendek Melalui Pembelajaran Kooperatif STAD Kelas VA SD Santo Yoseph YPPK 1 Tahun Akademik 2016/2017.

\begin{tabular}{|c|c|c|c|c|c|c|}
\hline No & value $(x)$ & & $\mathbf{F x}$ & $\mathbf{P}$ & Category & Average Value \\
\hline 1) & (2) & (3) & (4) & (5) & (6) & (7) \\
\hline 1 & 10 & - & - & - & - & \multirow{9}{*}{$\begin{array}{l}\frac{114}{23}=5,00 \\
\text { (Almots Enough) }\end{array}$} \\
\hline 2 & 9 & - & - & - & - & \\
\hline 3 & 8 & - & - & - & - & \\
\hline 4 & 7 & - & - & - & - & \\
\hline 5 & 6 & 7 & 42 & 30.4 & Enough & \\
\hline 6 & 5 & 8 & 40 & 34.8 & Almots Enough & \\
\hline 7 & 4 & 8 & 32 & 34.8 & less & \\
\hline 8 & 3 & - & - & - & - & \\
\hline 9 & 2 & - & - & - & - & \\
\hline
\end{tabular}




\begin{tabular}{|c|c|c|c|c|l|l|}
\hline 10 & 1 & - & - & - & - \\
\hline Jumlah & 23 & 114 & $100 \%$ & \\
\hline
\end{tabular}

menunjukkan bahwa nilai rata-rata sehingga kemampuan menganalisis unsur mencapai 5,00 siswa dari 23 siswa di intrinsik cerpen oleh STAD pada siklus kelas 6 rincian cukup 7 orang $(30,4 \%)$, pertama dapat dikategorikan ke dalam nilai lima kategori hampir cukup kelompok yang hampir cukup.

sebanyak 8 orang $(34,8 \%)$, Kategori

Tabel 3. Analisis Data Siklus II Peningkatan Unsur Intrinsik Menganalisis Cerita Pendek Melalui Pembelajaran Kooperatif STAD Kelas VA SD Santo Yoseph YPPK 1 Tahun Akademik 2016/2017.

\begin{tabular}{|c|c|c|c|c|c|c|}
\hline No & Value $(x)$ & $\mathbf{F}$ & $\mathbf{F x}$ & $\mathbf{P}$ & Category & Average Value \\
\hline (1) & (2) & (3) & (4) & (5) & (6) & (7) \\
\hline 1 & 10 & - & - & - & - & \multirow{11}{*}{$\begin{array}{l}\frac{177}{23}=7,70 \\
2 \text { more than enough) }\end{array}$} \\
\hline 2 & 9 & - & - & - & - & \\
\hline 3 & 8 & 16 & 128 & 69.6 & Good & \\
\hline 4 & 7 & 7 & 49 & 30.4 & more than enough & \\
\hline 5 & 6 & - & - & - & - & \\
\hline 6 & 5 & - & - & - & - & \\
\hline 7 & 4 & - & - & - & - & \\
\hline 8 & 3 & - & - & - & - & \\
\hline 9 & 2 & - & - & - & - & \\
\hline 10 & 1 & - & - & - & - & \\
\hline \multicolumn{2}{|c|}{ Jumlah } & 23 & 177 & $100 \%$ & - & \\
\hline
\end{tabular}

Data dalam tabel di atas, menunjukkan bahwa nilai rata-rata yang dicapai oleh siswa adalah 7,70, dari 23 siswa, terdiri dari 8 kategori nilai baik sebanyak 16 orang $(69,6 \%)$, nilai 7 kategori lebih dari cukup sebanyak 7 orang $(30,4 \%)$, sehingga kemampuan menganalisis unsur intrinsik cerpen oleh STAD pada siklus II dapat dikategorikan ke dalam kelompok lebih dari cukup, ketentuan sudah mencapai target, peneliti tidak perlu melanjutkan ke siklus selanjutnya.

\section{PENUTUP}

Hasil penelitian yang disajikan di atas, kemudian berdasarkan hasil observasi dan evaluasi tes kemampuan siswa dalam menganalisis unsur intrinsik cerpen melalui pembelajaran kooperatif tipe STAD. Dapat dilihat dari hasil yang diperoleh siswa pada setiap siklus mulai tes awal, siklus I, dan siklus II.

Kemampuan untuk menganalisis elemen intrinsik cerpen pada tes awal 
siswa mencapai skor rata-rata 4,00. Dari hasil yang diperoleh menunjukkan bahwa kemampuan menganalisis unsur intrinsik cerpen melalui pembelajaran kooperatif tipe STAD dalam tes awal dapat dikategorikan kurang, oleh karena itu penelitian tindakan kelas diadakan di YPPK Santo Yoseph 2 Distrik Biak. Hal yang sama juga ditemukan oleh Wahid (2004: 86) bahwa unsur intrinsik adalah unsur yang membentuk sebuah karya sastra.

Elemen tersebut ditemui jika kita telah membaca karya sastra. Elemen intrinsik dari sebuah cerita pendek adalah sebuah elemen yang dapat secara langsung membangun cerita dan keterpaduan antara elemen-elemen yang membuat cerita pendek menjadi kenyataan. Pembaca dapat dengan mudah menentukan elemen intrinsik yang terkandung dalam cerita. Elemen intrinsik adalah elemen yang membentuk karya sastra dalam hal penokohan, tema, mandat, latar belakang, alur, dan gaya bahasa.

Pada siklus I siswa mencapai nilai rata-rata 5,00 yang dikategorikan hampir cukup. Dari hasil yang diperoleh diketahui bahwa siswa mengalami peningkatan. Dalam proses pembelajaran berlangsung dengan baik tetapi masih ada masalah yang muncul pada siklus pertama siswa masih ragu untuk bertanya kepada peneliti yang walaupun peneliti memberikan kesempatan kepada siswa untuk mengajukan pertanyaan. Hal ini terjadi karena siswa belum cermat dan teliti dalam menganalisis unsur intrinsik cerpen melalui pembelajaran kooperatif tipe STAD, maka peneliti perlu melanjutkan pembelajaran ke siklus II.

Dalam buku Volume Bahasa Indonesia I yang diterbitkan Pusat Bahasa Kementerian Pendidikan Nasional disebutkan bahwa karakter (karakter) adalah seseorang yang memainkan peran tertentu dalam cerita. Dalam prosa, karakter adalah orang yang menjadi aktor yang menjalankan alur cerita. Dalam pengertian yang disebutkan di atas dapat disimpulkan bahwa yang disebut tokoh-tokoh dalam sebuah cerita adalah mereka yang berperan atau yang mengalami peristiwa dalam sebuah cerita (Santika, 2021).

Secara garis besar karakter atau karakterisasi karakter dapat diekspresikan dalam dua cara: (1) cara langsung (ekspositori) yang langsung atau jitu, mengekspresikan karakter karakter secara langsung dan dijelaskan oleh penulis. Penulis dengan jelas menggambarkan atau menggambarkan karakter karakter dan (2) cara tidak langsung (dramatis) untuk mengekspresikan karakter karakter secara tidak langsung melalui plot. Sejalan dengan Aschalew (2012: 74) menyatakan bahwa: Kita hidup di dunia yang dinamis di mana segala sesuatu 
berubah. Akibatnya, apa yang kita anggap benar hari ini mungkin salah besok dan apa yang kita anggap salah hari ini mungkin benar besok.

Karena itu, kita harus beradaptasi dengan dunia yang berubah atau memodifikasinya agar sesuai dengan kebutuhan kita. Ini adalah pendidikan yang memungkinkan kita untuk melakukannya. Ini berarti bahwa pendidikan memungkinkan kita untuk hidup lebih baik di dunia yang dinamis ini. Dalam hal ini, pendidikan telah mengalami perubahan terus-menerus. Karena banyak kelemahan dengan pendekatan yang berpusat pada guru, metode pembelajaran aktif diteliti dan didukung oleh banyak sarjana.

Pada siklus kedua, siswa mencapai skor rata-rata 7,70 yang dikategorikan lebih dari cukup. Dari hasil yang diperoleh siswa diketahui bahwa kemampuan menganalisis unsur intrinsik cerpen melalui pembelajaran kooperatif tipe STAD mengalami peningkatan, juga terlihat dari setiap individu banyak siswa yang mendapat nilai bagus karena selama proses pembelajaran berlangsung semua siswa bermain peran aktif, siswa tidak lagi enggan bertanya dan keaktifan siswa dalam menganalisis unsur intrinsik cerpen dengan sangat baik. Berdasarkan hasil yang dicapai, peneliti merasa tidak perlu lagi melanjutkan pelaksanaan pembelajaran untuk menganalisis elemen intrinsik cerpen melalui pembelajaran kooperatif tipe STAD, karena hasil yang diperoleh siswa telah mencapai kriteria nilai baik yang ditentukan oleh peneliti.

Adapun hasil peningkatan
pembelajaran menganalisis cerpen
melalui metode cooprative tipe STAD di
kelas VA SD YPPK Saint Yoseph 1 Biak
Numfor Kabupaten Pelajaran Tahun
2016/2017 dari tes awal, siklus I, dan
siklus II dapat dilihat pada grafik di
bawah


Available Online at http://ejournal.undwi.ac.id/index.php/widyaaccarya/index

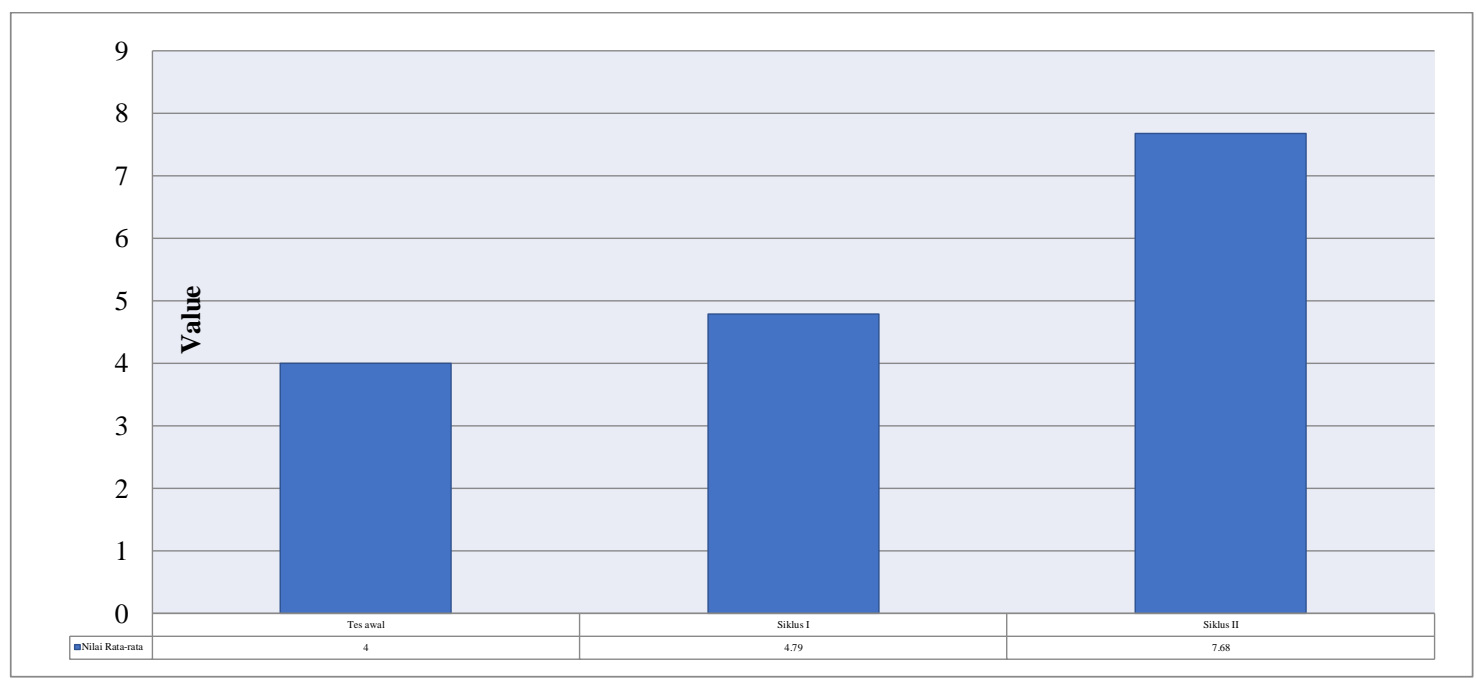

Gambar 1. Hasil Menganalisis Pembelajaran Cerpen Metode Pembelajaran Kooperatif Menggunakan STAD Di Kelas VA SD YPPK St. Joseph 1 Biak Noemfoor. untuk Tes Awal, Siklus I dan II

\section{DAFTAR PUSTAKA}

Aschalew T. (2012). Persepsi Guru Dan Praktik Pembelajaran Aktif Di Universitas Haramaya, Ethiopia Timur: Kasus Fakultas Pendidikan. Jurnal Penelitian, 1 (4), 74-83.

Isjoni. (2010). Pembelajaran Kooperatif Meningkatkan Kecerdasan Komunikasi Di antara Peserta Didik. Yogyakarta: Sastra Mahasiswa.

Iskandar. (2010). Penelitian Tindakan Kelas. Jakarta: Gaung Persada Press.

Kosasih. (2012).

Dasar-dasar Keterampilan Besastra. Bandung.Yrama Widya.

N. H, Peni. (2010). Jurnalisme: Media Anak Kreatif. Surabaya: Insan Cendekia.

Nurkancana, I Wayan \& Sunartana. (1992). Evaluasi Pendidikan. Surabaya: Bisnis Nasional
Poerwadarminta, W.J., S. (2011). Kamus Umum Bahasa Indonesia: Edisi Ketiga.

Rusman. (2011). Model Pembelajaran, Cetak Keempat. Jakarta: PT. Raja Grafindo Persada.

Santika, I. G. N. (2018). Strategi Meningkatkan Kualitas SDM Masyarakat Desa Padangsambian Kaja Melalui Pendidikan Karakter Berbasiskan Kepedulian Lingkungan Untuk Membebaskannya Dari Bencana Banjir. Widya Accarya. 9 (2).

Santika, I. G. N. (2021). Pendidikan Kewarganegaraan (Studi Komparatif Konstitusi Dengan UUD 1945). Jawa Tengah: Lakeisha

Santika, I Gusti Ngurah. 2017. Kepala Sekolah Dalam Konsep Kepemimpinan Pendidikan: Suatu Kajian Teoritis. Widya Accarya. 7 (1) 
Santika, I. G. N. (2020). Optimalisasi Peran Keluarga Dalam Menghadapi Persoalan Covid19: Sebuah Kajian Literatur. Jurnal Ilmiah Ilmu Sosial. 6 (2), 127-137. http://dx.doi.org/10.23887/jiis. v6i2.28437

Swarniti, N. W. (2019). The Translation Procedures of Bible Translation. RETORIKA: Jurnal Ilmu Bahasa, 5(2), 187-196.

https://doi.org/10.22225/jr.5.2. 1277.187-196

Swarniti, N. W. (2021). A Corpus Based Approach to the Analysis of Structures in Prepositional Phrase. Yavana Bhasha: Journal of English Language Education, 4(1), 18-22.

Tarigan, Henry Thunder. (1984). Prinsip-Prinsip Dasar Sastra. Bandung: Luar Angkasa.

Trianto. (2010). Model Pembelajaran Terintegrasi. Jakarta: Literasi Bumi. 